\title{
Editorial
}

Journal of Innate
Immunity
J Innate Immun 2009;1:281

DOI: $\underline{10.1159 / 000210451}$

Published online: March 31, 2009

\section{The Tinkerer at Work}

In a landmark paper in 1977, Francois Jacob [1] likened the evolutionary process to the work of a tinkerer who uses a toolbox of elements shaped by their present function and previous history and assembles them for novel functions. Jacob [1] proposed 3 mechanisms of assembly: gene duplication, reshuffling of genes or parts of genes and recruitment for more than 1 function. In this issue on invertebrate immunity, ample evidence for tinkering during immune system evolution is presented. Rosenstiel and colleagues [2] summarize work on immune receptors from marine invertebrates. Both expansion and reduction in receptor families provide a rich source for studying immune adaptations towards different abiotic and biotic factors of the environment. Local adaptations in the evolutionary landscape are suggested by the work of Bidla et al. [3] who show that phenoloxidase, one of the key enzymes involved in arthropod immunity, is used in different ways in separate insect species and at different time points during an infection. Stanley and colleagues [4] summarize how inhibitors of eicosanoid synthesis affect several aspects of insect immunity and provide some first hints of the underlying molecular mechanisms and their effects on cellular immunity. Towb and colleagues [5] take the part of the evolutionary tinkerer by creating an in vitro fusion of a protein that combines elements of 2 separate Drosophila kinases involved in Toll signaling, thus mimicking potential ancestor enzymes in other species. Quite amazingly, the fusion construct can largely rescue the embryonic defects in double mutants of the individual kinases. Defaye and colleagues [6] answer some long-standing questions about the role of cellular immunity in invertebrates by genetically eliminating Drosophila blood cells (hemocytes). The resulting animals show both developmental and immune defects. Finally, Michael Williams [7] describes novel aspects of his work on Drosophila blood cells, which spread to form capsules around large foreign objects similar to what occurs during granuloma formation in vertebrates. These results show that we are able to study the traces left by the tinkerer and get an understanding for the achievements but also the imperfections, which have shaped the toolbox of insect immune genes and domains.

Ulrich Theopold, Stockholm

David Schneider, Stanford, Calif.

\section{References}

1 Jacob F: Evolution and tinkering. Science 1977;196:1161-1166.

-2 Rosenstiel P, Philipp EER, Schreiber S, Bosch TCG: Evolution and function of innate immune receptors - insights from marine invertebrates. J Innate Immun 2009;1:291300.

3 Bidla G, Hauling T, Dushay MS, Theopold U: Activation of insect phenoloxidase after injury: endogenous versus foreign elicitors. J Innate Immun 2009;1:301-308.
4 Stanley D, Miller J, Tunaz H: Eicosanoid actions in insect immunity. J Innate Immun 2009; 1:282-290.

5 Towb P, Sun H, Wasserman SA: Tube is an IRAK-4 homolog in a Toll pathway adapted for development and immunity. J Innate Immun 2009;1:309-321.
6 Defaye A, Evans I, Crozatier M, Wood W, Lemaitre B, Leulier F: Genetic ablation of Drosophila phagocytes reveals their contribution to both development and resistance to bacterial infection. J Innate Immun 2009; 1:322-334.

7 Williams MJ: The c-src homologue Src64B is sufficient to activate the Drosophila cellular immune response. J Innate Immun 2009; 1:335-339.

\begin{tabular}{ll}
\hline KARGER & @ 2009 S. Karger AG, Basel \\
1662-811X/09/0014-0281\$26.00/0 \\
$\begin{array}{l}\text { E-Mail karger@karger.ch } \\
\text { www.karger.com }\end{array}$ & $\begin{array}{l}\text { Accessible online at: } \\
\text { www.karger.com/jin }\end{array}$
\end{tabular}

